\title{
Production of Arbuscular Mycorrhizal Fungi using In vitro Root Organ Culture and Phenolic Compounds
}

\author{
Sawsan Abd Ellatif ${ }^{1}\left(\mathbb{D}\right.$, Eman Abdullah M. Ali ${ }^{2 *}(\mathbb{D})$, Hoda H. Senousy ${ }^{2}$ and \\ Elsayed S. Abdel Razik ${ }^{3}$ D
}

${ }^{1}$ Bioprocess Development Department, Genetic Engineering and Biotechnology Research Institute (GEBRI), City for Scientific Research and Technology Application, New Borg El-Arab, 21934, Alexandria, Egypt. ${ }^{2}$ Botany and Microbiology Department, Faculty of Science, Cairo University, 12613, Giza, Egypt. ${ }^{3}$ Plant Protection and Biomolecular Diagnosis Department, Arid Lands Cultivation Research Institute, City for Scientific Research and Technology Application, New Borg El-Arab,21934,Alexandria, Egypt.

\begin{abstract}
Arbuscular mycorrhizal fungi form obligate symbiotic associations with most of plant families. This limits their in vitro culturing and large-scale production. In vitro root organ culture is very useful for studying these symbiotic relationships and for mass production of arbuscular mycorrhizal fungal inoculants. This research aimed to study the effect of different phenolic compounds on the growth of the arbuscular mycorrhizal fungus Gigaspora gigantea using in vitro tomato root organ culture. Eight phenolic compounds were used against control without phenolic compounds. The phenolic compounds used in this research were cinnamic acid, catechin anhydrous, protocatechuic acid, ferulic acid, tannic acid, coumarin, esculetin and catechol. The experiments were done at two different pHs (5.7 and 6.5) in both solid and liquid media. Phenolic compounds exhibited different effects including stimulatory, inhibitory or no effects. Catechin anhydrous (which is a flavonoid compound) showed the most significant increase in both mycorrhizal root colonization and arbuscular abundance with moderate growth of root hairs at $\mathrm{pH}$ 6.5. Tannic acid inhibited the growth of root hairs, mycorrhizal colonization and formation of arbuscules at pH 5.7. Solid media were superior to liquid media in both mycorrhizal colonization and arbuscular formation.
\end{abstract}

Keywords: Arbuscular mycorrhizal fungi, Gigaspora gigantea, Phenolic compounds, In vitro root organ culture, Symbiosis, Transformation.

*Correspondence: emanali@sci.cu.edu.eg; +201222643685.

(Received: 15 September 2019; accepted: 29 October 2019)

Citation: Sawsan Abd Ellatif, Eman Abdullah M. Ali, Hoda H. Senousy and Elsayed S. Abdel Razik, Production of Arbuscular Mycorrhizal Fungi using in Vitro Root Organ Culture and Phenolic Compounds, J Pure Appl Microbiol., 2019; 13(4):1985-1994. https://doi.org/10.22207/JPAM.13.4.10

(C) The Author(s) 2019. Open Access. This article is distributed under the terms of the Creative Commons Attribution 4.0 International License which permits unrestricted use, sharing, distribution, and reproduction in any medium, provided you give appropriate credit to the original author(s) and the source, provide a link to the Creative Commons license, and indicate if changes were made. 


\section{INTRODUCTION}

Arbuscular mycorrhizal fungi (AMF) are a very important component occurring in the rhizosphere ${ }^{1}$. They form an obligate symbiotic association with the roots of $90 \%$ of the terrestrial plants species ${ }^{2,3}$. This means that each step of their life cycle requires the association with a living plant.

AMF can stimulate plant growth by increasing nutrients uptake (particularly immobile elements like $\mathrm{P}, \mathrm{Zn}$ and $\mathrm{Cu}$ ), enhancing growth regulating materials, improving osmotic adjustment under drought and salinity stresses, stimulating photosynthesis and increasing plant resistance against pathogens ${ }^{4-8}$. The extensive extra radical mycelial networks of mycorrhizal fungi aid plants to obtain nutrients and water from soils which plant roots cannot reach ${ }^{2}$. AMF also reduce the applied quantities of fertilizers to soils?.

The pot culture is the common method of vesicular-arbuscular mycorrhizal (VAM) fungal inoculum production. There are many problems with pot culture. Regulation of some conditions such as $\mathrm{pH}$ and mineral levels is cost and hard. These things can inhibit VAM colonization or sporulation reducing the quality of an inoculum ${ }^{10}$.

The obligatory symbiotic nature of AMF limits the large-scale production of mycorrhizal inoculums to satisfy the farmer needs which force us to make another strategy for more aseptic production of arbuscular mycorrhizal propagules $^{11}$.

The in vitro root organ culture establishment has large potential in understanding the symbiosis of AMF and the production of monoxenic inoculum ${ }^{12}$. Cultivation of VAM fungi in transgenic hairy roots is a powerful tool to study its biology and this method can be used for the mass production of VAM fungal monoxenic inocula ${ }^{13}$.

The use of excised roots as host partner in AMF symbiosis was first introduced by Mosse and Hepper ${ }^{14}$. They established monoxenic culture of Glomus mosseae in hairy roots initiated through inoculation with Agrobacterium rhizogenes. Hairy roots, which are biochemically and genetically stable, are able to grow in hormone-free media. Transformation of roots by the soil-borne bacterium Agrobacterium rhizogenes provided a novel way for mass production of roots in a very short time with using relative poor substrates ${ }^{11}$. Agrobacterium rhizogenes carries a large plasmid containing transfer DNA (T-DNA). When contact with host plant, it inserts copies of T-DNA using its own DNA delivery mechanism ${ }^{15}$. The inserted DNA fragment carries genes for growth hormones and the transformed roots have a rapid, strong and homogenous root growth. Another important feature of the transformed hairy roots is the negative geotropism which facilities contacts with AMF hyphae ${ }^{16,17}$.

Phenolic compounds are a big class of plant secondary metabolites, displaying a variety of structures, from simple structures (such as phenolic acids) through polyphenols (as flavonoids which comprise many groups) to polymeric compounds (depend on these different classes) ${ }^{18}$. Phenolic compounds, particularly flavonoids, enhance spore germination, mycelial growth and ramification of numerous $\mathrm{AMF}^{19,20}$, in addition to the stimulation of colonization of roots ${ }^{21}$.

The formation of the arbuscular mycorrhizal symbiosis is a result of a complex signals exchange between AMF and hosts. Flavonoids are secondary compounds present in root exudates. They have been reported as important signalling compounds for plant microbe interactions in the soil. These interactions such as plant interactions with nitrogen fixing rhizobia and arbuscular mycorrhizal fungi ${ }^{22}$. An obvious effect of some flavonoids on the pre symbiotic AMF development has been stated ${ }^{23-25}$. The flavonol morin and the flavones luteolin and chrysin display a stimulatory effect on the pre symbiotic hyphal growth of numerous Gigaspora and Glomus species, while the flavonols isorhamnetin, rutin, and kaempferol enhance hyphal growth of Gigaspora but not Glomus species ${ }^{26}$.

The main purpose of this study was to provide a simple, inexpensive, contamination-free, continuous and effective method for the in vitro mass production of $G$. gigantea propagules (spores and hyphae). This was by using in vitro tomato root organ culture with exogenous application of phenolic compounds.

\section{MATERIALS AND METHODS \\ Establishment of pot culture}

Gigaspora gigantea (T.H. Nicolson \&

Gerd.) Gerd. \& Trappe was isolated from soil, 
identified morphologically and propagated in greenhouse pot culture with tomato as host. Tomato plant (Solanum lycopersicum L.) were cultivated in plastic pots containing $1 \mathrm{~L}$ of a sterelized mixture of sand and clay soils (1:1 $\mathrm{v} / \mathrm{v}$ ), with $\mathrm{pH} 4.8-5.2$, modified with $5.5 \mathrm{~g} / \mathrm{Kg}$ of rock phosphate and fertilized occasionally with $1 / 10$ strength nutrient solution without $P^{27}$. After growth for 4 month, the contents of the pot were desiccated and roots were detached. The pot culture was kept at refrigerator till demanded ${ }^{28}$.

\section{Isolation of spores from root-soil mixtures}

Spores were isolated from pot culture by wet sieving and decanting method ${ }^{29}$.

\section{Spore sterilization}

Isolated spores were surface sterilized by addition of ethanol (98\%) for 10 minutes, then rinse with sterile distilled water. After that, calcium hypochlorite (2\%) was added for 2 minutes, then rinse with sterile distilled water 3 times. Chloramin $\mathrm{T}(2 \%)$ and tween 20 ( 2 drops) were then added for 10 minutes followed by rinsing with sterile distilled water. Antibiotic solutions were then added in two steps. Streptomycin sulphate $(0.02 \%)$ was added firstly then gentamicin sulphate $(0.01 \%)$ by using syringe filter. Spores were put in fresh sterile petriplate with fresh antibiotics. After surface sterilization, spores were transferred with a micropipette to modified Strullu-Romand (MSR) plates. Medium was solidified with $5 \mathrm{~g} / \mathrm{L}$ phytagel and was used as a growing medium ( $\mathrm{pH}$ 5.5). Plates were incubated at $27^{\circ} \mathrm{C}$ in the dark ${ }^{30}$.

Establishment of in vitro aseptic cultures of tomato plants

Tomato seeds were surface sterilized by treatment with a solution of $70 \%(\mathrm{v} / \mathrm{v})$ ethanol for 3 minutes, followed by $20 \%(\mathrm{v} / \mathrm{v})$ commercial Clorox solution for 10 minutes. The sterilized seeds were rinsed several times with sterile distilled water. By using a Laminar Flow Cabinet sterilized by UV lamp, the sterilized seeds were aseptically transferred and germinated on Murashige and Skooge (MS) basal solid medium ${ }^{31}$ which consists of $4.5 \mathrm{~g} / \mathrm{L} \mathrm{MS}$ salts supplemented with $30 \mathrm{~g} / \mathrm{L}$ sucrose. Cultured seeds were incubated in a growth chamber at $25^{\circ} \mathrm{C}$ and 16 hours photoperiod (white fluorescent light). Leaves of 1-1.5 month old of tomato seedlings were used as a source of explants for transformation.

\section{Bacterial inoculum}

A4 and R1000 strains of Agrobacterium rhizogenes were used for transformation. To screen and select the required colony, bacteria from glycerol stock culture were grown on LuriaBertani (LB) solid medium [yeast extract $(5 \mathrm{~g} / \mathrm{L})$, peptone (10g/L), $\mathrm{NaCl}(10 \mathrm{~g} / \mathrm{L}) ; \mathrm{pH} 7.0]$ contains $50 \mathrm{mg} / \mathrm{L}$ kanamycin. One colony was incubated in $20 \mathrm{ml} \mathrm{LB}$ medium on rotary shaker (130 rpm) for $12-16 \mathrm{~h}$ at $28^{\circ} \mathrm{C}^{17}$. Centrifugation was done at $4^{\circ} \mathrm{C}, 4200 \mathrm{rpm}$ for $15 \mathrm{~min}$ to harvest bacterial cells. Pellets were resuspended in $20 \mathrm{ml}$ liquid MS medium and were used to infect tomato explants. Transformation and establishment of hairy root cultures

Explants of $1 \mathrm{~cm}^{2}$ pieces were cut aseptically from leaves of 1-1.5 month old tomato seedlings and were immersed for 30 minutes in $20 \mathrm{ml}$ bacterial suspension. Explants were dried with sterile filter paper and transferred on MS plates without hormones. Plates were incubated in complete darkness at $25^{\circ} \mathrm{C}$. Hairy roots (4-6 $\mathrm{cm}$ in length) were removed from explants and transferred onto fresh MS plates ${ }^{11}$.

\section{Effect of phenolic compounds on production of} AM fungal propagules

G. gigantea spore suspension was used to inoculate transformed roots of tomato in MSR medium to test their ability to produce new colonies and spores. Eight treatments were used consisting of filter sterilized phenolic compounds at concentration of $10 \mu \mathrm{M}$ in methanol, added in both liquid and solid media then mixed well, against a control free from phenolic compounds. The phenolic compounds used in these treatments were cinnamic acid, catechin anhydrous, protocatechuic acid, ferulic acid, tannic acid, coumarin, esculetin and catechol. Each experiment was divided into two subsets with two different pHs, 5.7 and 6.5 (that denoted in some literatures the best ones to spore differentiation). Each treatment was contained three replicates. After 3 weeks of incubation at $27^{\circ} \mathrm{C}$, the spore numbers were recorded by taking a $0.5 \mathrm{ml}$ of liquid media and counting the spores from each treatment.

\section{Staining of roots by trypan blue}

The staining was done according modified Philips and Hayman method ${ }^{32}$. Roots were collected, carefully washed, and macerated in $10 \%$ 
$\mathrm{KOH}$. Then they were rinsed in water. The roots were then acidified in $5 \%$ lactic acid for 24 hours. Roots were then stained with $0.03 \%$ trypan blue in lactic acid: glycerol: $\mathrm{H}_{2} \mathrm{O}(1: 1: 1 \mathrm{v} / \mathrm{v} / \mathrm{v})$. Roots were cut into pieces of $1 \mathrm{~cm}$. They were covered with mixture of lactic acid: glycerol $(1: 5 \mathrm{v} / \mathrm{v})^{33}$.

\section{Estimation of AMF colonization}

The microscopic estimation of mycorrhizal colonization of roots was done according to Trouvelot et al. method ${ }^{34}$. Thirty root segments were chosen randomly from the stained samples, put on two microscopic slides (15 segments/slide), and carefully crushed with the cover glass. These segments were observed under stereomicroscope for the presence or absence of AMF functional structures (mycelium and arbuscules). The degree of mycorrhizal colonization of each root segment and the abundance of arbuscules were estimated.

The results of the mycorrhizal colonization and abundance of arbuscules were used to calculate the following parameters: F\% (mycorrhizal frequency), $\mathrm{M} \%$ (relative mycorrhizal intensity; for the whole sample), $\mathrm{m} \%$ (absolute mycorrhizal intensity; for the segments in which there were indication of colonization by mycorrhizal fungi), a\% (absolute abundance of arbuscules; for the segments in which arbuscules were present) and A\% (relative abundance of arbuscules; for the whole sample) using the 'Mycocalc' software (http://www.dijon.inra.fr/mychintec/Mycocal prg/ download.html). The previous parameters were calculated using the following equations:

Table 1. Scoring of external appearance of root hairs growth in liquid media

\begin{tabular}{lcc}
\hline Treatment & pH 6.5 & pH 5.7 \\
\hline Cinnamic acid & 4 & 1 \\
Catechin anhydrous & 3 & 3 \\
Protocatechuic acid & 2 & 4 \\
Ferulic acid & 3 & 5 \\
Tannic acid & 3 & 0 \\
Coumarin & 5 & 3 \\
Esculetin & 2 & 2 \\
Catechol & 3 & 4 \\
Control & 3 & 3
\end{tabular}

0 : no root hairs, 1: very few root hairs, 2 : few root hairs, 3 : moderate root hairs, 4 : more root hairs, 5 : dense root hairs.
$\mathrm{F} \%=\left(\mathrm{I}_{\mathrm{m}} / \mathrm{I}_{\mathrm{t}}\right) * 100$

$M \%=\left(95 n_{5}+70 n_{4}+30 n_{3}+5 n_{2}+n_{1}\right) / I_{t}$

$\mathrm{m} \%=\mathrm{M} \% * \mathrm{I}_{\mathrm{t}} / \mathrm{I}_{\mathrm{m}}=\mathrm{M} \% * 100 / \mathrm{F}$

$$
\begin{aligned}
& a \%=(100 * m \% A 3+50 * m \% A 2+10 * m \% A 1) \\
& / 100 \\
& A \%=a \% * 0.01 M \%
\end{aligned}
$$

Where:

$I_{m}$ is the total number of root segments in which mycelium were found.

$I_{t}$ is the total number of the examined segments.

$n_{5}-n_{1}$ is the total number of root segments in which the degree of colonization by mycorrhizal structures was 5-1.

$m \% A 3, m \% A 2, m \% A 1$ are the \% of $m$, rated $A 3, A 2, A 1$, respectively, with $m \% A 3=$ $\left(95 * n_{5} A 3+70 * n_{4} A 3+30 * n_{3} A 3+5 * n_{2} A 3+n_{1} A 3\right) /$ $I_{m}^{*} 100 / m \%$ and the same for $A 2$ and $A 1$.

\section{Statistical analysis}

The results were displayed as mean \pm standard deviations (mean \pm SD). Data were evaluated by one-way analysis of variance (ANOVAs) using SPSS statistical software. The differences between mean values were evaluated with Duncan's test at $p \leq 0.05$.

Table 2. Number of spores (spore density per $\mathrm{ml}$ culture) in liquid media

\begin{tabular}{lcc}
\hline Treatment & $\mathrm{pH} 6.5$ & $\mathrm{pH} 5.7$ \\
\hline Cinnamic acid & $150^{\mathrm{e}} \pm 2.00$ & $150^{\mathrm{e}} \pm 6.23$ \\
Catechin anhydrous & $100^{\mathrm{d}} \pm 2.65$ & $150^{\mathrm{e}} \pm 5.00$ \\
Protocatechuic acid & $105^{\mathrm{d}} \pm 5.00$ & $21^{\mathrm{a}} \pm 1.00$ \\
Ferulic acid & $45^{\mathrm{c}} \pm 3.00$ & $100^{\mathrm{d}} \pm 4.59$ \\
Tannic acid & $22^{\mathrm{a}} \pm 2.00$ & $33^{\mathrm{b}} \pm 2.65$ \\
Coumarin & $34^{\mathrm{b}} \pm 2.65$ & $100^{\mathrm{d}} \pm 5.20$ \\
Esculetin & $32^{\mathrm{b}} \pm 2.65$ & $55^{\mathrm{c}} \pm 3.61$ \\
Catechol & $50^{\mathrm{c}} \pm 2.00$ & $250^{\mathrm{f}} \pm 5.00$ \\
Control & $31^{\mathrm{b}} \pm 4.36$ & $31^{\mathrm{b}} \pm 2.65$ \\
\hline
\end{tabular}

Values are means of triplicate readings \pm standard deviation (mean $\pm S D$ ). Across the same column, mean values with different letters are significantly different at $5 \%$ level according to Duncan's multiple range test. 


\section{RESULTS}

Effect of phenolic compounds on production of G. gigantea propagules and root hairs growth in liquid media

These experiments were done to test the effect of different phenolic compounds on the production of $G$. gigantea propagules and root hairs growth in liquid media under two different $\mathrm{pHs}, 5.7$ and 6.7.

The data presented in Table (1) indicated that all phenolic compounds used at $\mathrm{pH} 6.5$ activated root hairs growth. Coumarin was the most effective phenolic compound followed by cinnamic acid. At pH 5.7, ferulic acid activated root hairs growth with the highest rate followed by protocatechuic acid and catechol. No root hairs are formed by using tannic acid. Moderate appearance of root hairs in control treatments

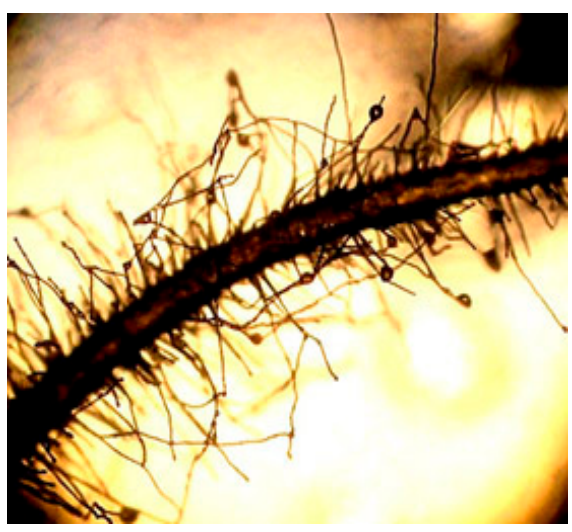

Fig. 1. Treatment with catechin anhydrous at $\mathrm{pH} 6.5$

Table 3. Scoring of mycorrhizal colonization (0-5) in liquid media

\begin{tabular}{lcc}
\hline Treatment & pH 6.5 & pH 5.7 \\
\hline Cinnamic acid & 5 & 1 \\
Catechin anhydrous & 5 & 1 \\
Protocatechuic acid & 4 & 1 \\
Ferulic acid & 5 & 1 \\
Tannic acid & 2 & 0 \\
Coumarin & 4 & 1 \\
Esculetin & 2 & 1 \\
Catechol & 1 & 1 \\
Control & 1 & 1
\end{tabular}

0: $0 \%, 1:<1 \%, 2:<10 \%, 3:<50 \%, 4:>50 \%, 5:>90 \%$.
As shown in Table (2), the using of different phenolic compounds at $\mathrm{pH} 5.7$ resulted in higher spore density than using them at pH 6.5 except when using protocatechuic acid. Catechol was the most significant phenolic compound in increasing spores number at $\mathrm{pH} 5.7$, while cinnamic acid was the most significant one at $\mathrm{pH}$ 6.5 .

The data in Table (3) displayed the effect of different phenolic compounds on mycorrhizal colonization of tomato roots using microscopic examination of roots according to Trouvelot et al. method ${ }^{34}$. It was obvious that the effects of phenolic compounds on mycorrhizal colonization were $\mathrm{pH}$-dependent, where $\mathrm{pH} 6.5$ was more significant than $\mathrm{pH}$ 5.7. At $\mathrm{pH} 5.7$, few hyphae were observed at all treatments except by using tannic acid where, no colonization was observed. At pH

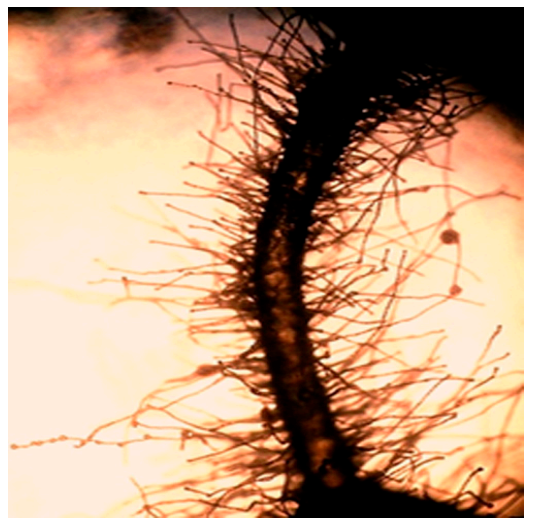

Fig. 2. Treatment with protocatechuic acid at $\mathrm{pH} 6.5$

Table 4. Scoring of arbuscular abundance in liquid media

\begin{tabular}{lcc}
\hline Traetment & $\mathrm{pH} 6.5$ & $\mathrm{pH} 5.7$ \\
\hline Cinnamic acid & $\mathrm{A} 1$ & $\mathrm{~A} 1$ \\
Catechin anhydrous & $\mathrm{A} 3$ & $\mathrm{~A} 2$ \\
Protocatechuic acid & $\mathrm{A} 2$ & $\mathrm{~A} 3$ \\
Ferulic acid & $\mathrm{A} 2$ & $\mathrm{~A} 2$ \\
Tannic acid & $\mathrm{A} 0$ & $\mathrm{~A} 0$ \\
Coumarin & $\mathrm{A} 2$ & $\mathrm{~A} 2$ \\
Esculetin & $\mathrm{A} 0$ & $\mathrm{~A} 3$ \\
Catechol & $\mathrm{A} 2$ & $\mathrm{~A} 2$ \\
Control & $\mathrm{A} 1$ & $\mathrm{~A} 2$
\end{tabular}

A0: None, A1: few (less than 50\%), A2: moderate (50-75\%), A3: Abundant (75-100\%) 
6.5 , cinnamic acid, catechin anhydrous and ferulic acid caused significant activation of hyphal growth followed by protocatechuic acid and coumarin.

As demonstrated in Table (4), abundant arbuscules were achieved by using protocatechuic acid, esculetin (at pH 5.7) and catechin anhydrous (at $\mathrm{pH}$ 6.5). Moderate arbuscular abundance was attained by most of phenolic compounds treatments. Few arbuscular abundance was observed by using cinnamic acid. Inhibition of arbuscular formation was observed by using tannic acid (at both pHs) and esculetin (at pH 6.5).

From the previous data, it was noticeable that the effects of phenolic compounds differed with different $\mathrm{pHs}$. At pH 6.5, catechin anhydrous (a flavonoid compound) showed the most significant increase in both mycorrhizal root colonization and abundance of arbuscules with moderate root hairs growth. Tannic acid inhibited root hairs growth, mycorrhizal colonization and arbuscules formation at $\mathrm{pH}$ 5.7.

At $\mathrm{pH} 6.5$, the mean values of mycorrhizal frequency (F\%) were ranged from $13.33 \%$ to $93.33 \%$ which significantly differed by the type of phenolic compounds (Table 5). The highest significant value was detected using catechin anhydrous. At pH 5.7, the mycorrhizal frequency values were ranged significantly from $0.00 \%$ to $73.33 \%$. The highest significant values noticed by using catechin anhydrous, protocatechuic acid and esculetin. In the case of relative mycorrhizal intensity (M\%), the mean values were ranged with significant differences from $0.67 \%$ to $63.67 \%$ by using different phenolic compounds at the two tested $\mathrm{pHs}$. The highest significant values were observed by using catechin anhydrous at $\mathrm{pH} 6.5$ and esculetin at $\mathrm{pH}$ 5.7.

The absolute mycorrhizal intensity values (m\%) at $\mathrm{pH} 6.5$ were significantly lower than control for both cinnamic acid and esculetin. While, the other tested phenolic compounds showed no significant differences than control. At $\mathrm{pH}$ 5.7, the highest significant value was $91.88 \%$ with ferulic acid. The absolute abundance of arbuscules values (a\%) were significantly different by using different phenolic compounds, where catechin anhydrous (at $\mathrm{pH}$ 6.5) and coumarin (at pHs 6.5 and 5.7) showed the highest significant values.

The mean values of relative abundance of arbuscules (A\%) were ranged from $0.00 \%$ to $43.83 \%$ at $\mathrm{pH} 6.5$, while were ranged from $0.00 \%$ to $60.33 \%$ at $\mathrm{pH} 5.7$ which differed significantly by using different phenolic compounds. Catechin anhydrous and esculetin displayed the highest significant values at pHs 6.5 and 5.7, respectively.

At a brief description of the results shown in Table (5), it was observed that all mycorrhizal

Table 5. Parameters of mycorrhizal colonization and abundance of arbuscules in tomato roots grown in liquid media

\begin{tabular}{|c|c|c|c|c|c|c|c|c|c|c|}
\hline \multirow{2}{*}{$\begin{array}{l}\text { Parameter } \\
\text { Treatment }\end{array}$} & \multicolumn{2}{|c|}{$\mathrm{F} \%$} & \multicolumn{2}{|c|}{$\mathrm{M} \%$} & \multicolumn{2}{|c|}{$\mathrm{m} \%$} & \multicolumn{2}{|c|}{$a \%$} & \multicolumn{2}{|c|}{$\mathrm{A} \%$} \\
\hline & $\mathrm{pH} 6.5$ & $\mathrm{pH} 5.7$ & $\mathrm{pH} 6.5$ & $\mathrm{pH} 5.7$ & $\mathrm{pH} 6.5$ & $\mathrm{pH} 5.7$ & $\mathrm{pH} 6.5$ & $\mathrm{pH} 5.7$ & $\mathrm{pH} 6.5$ & $\mathrm{pH} 5.7$ \\
\hline Cinnamic acid & $20.00^{\mathrm{b}}$ & $33.33^{b}$ & $6.33^{b}$ & $16.47^{b}$ & $31.65^{b}$ & $36.40^{\mathrm{b}}$ & $47.70^{b}$ & $58.50^{\mathrm{b}}$ & $12.00^{c}$ & $11.40^{b}$ \\
\hline $\begin{array}{l}\text { Catechin } \\
\text { anhydrous }\end{array}$ & $93.33^{h}$ & $73.33^{e}$ & $51.00^{f}$ & $53.07^{\mathrm{ef}}$ & $54.64^{c}$ & $72.36^{\mathrm{ef}}$ & $99.06^{f}$ & $91.72^{\mathrm{e}}$ & $43.83^{f}$ & $48.67^{\circ}$ \\
\hline $\begin{array}{l}\text { Protocatechuic } \\
\text { acid }\end{array}$ & $73.33^{\mathrm{g}}$ & $73.33^{e}$ & $40.67^{e}$ & $57.67^{f}$ & $55.45^{c}$ & $78.64^{\mathrm{fg}}$ & $85.95^{e}$ & $93.93^{\mathrm{ef}}$ & $32.47^{e}$ & $54.17^{e}$ \\
\hline Ferulic acid & $13.33^{a}$ & $53.33^{c}$ & $6.40^{\mathrm{b}}$ & $49.00^{e}$ & $48.00^{c}$ & $91.88^{h}$ & $85.95^{e}$ & $97.24^{\mathrm{gh}}$ & $6.34^{b}$ & $46.67^{\circ}$ \\
\hline Tannic acid & $33.33^{d}$ & $0.00^{\mathrm{a}}$ & $17.47^{c}$ & $0.00^{\mathrm{a}}$ & $52.40^{c}$ & $0.00^{\mathrm{a}}$ & $0.00^{\mathrm{a}}$ & $0.00^{\mathrm{a}}$ & $0.00^{\mathrm{a}}$ & $0.00^{\mathrm{a}}$ \\
\hline Coumarin & $46.67^{\mathrm{e}}$ & $53.33^{c}$ & $25.53^{d}$ & $32.40^{c}$ & $54.71^{\mathrm{c}}$ & $60.75^{d}$ & $99.30^{f}$ & $98.79^{h}$ & $25.35^{d}$ & $32.01^{\circ}$ \\
\hline Esculetin & $13.33^{a}$ & $73.33^{e}$ & $0.67^{a}$ & $63.67^{g}$ & $5.00^{\mathrm{a}}$ & $86.82^{\mathrm{gh}}$ & $0.00^{\mathrm{a}}$ & $94.76^{\mathrm{fg}}$ & $0.00^{\mathrm{a}}$ & $60.33^{f}$ \\
\hline Catechol & $53.33^{f}$ & $60.00^{d}$ & $26.67^{d}$ & $38.73^{d}$ & $50.00^{c}$ & $64.56^{\mathrm{de}}$ & $61.38^{c}$ & $82.63^{d}$ & $16.38^{\mathrm{c}}$ & $32.01^{\circ}$ \\
\hline Control & $26.67^{c}$ & $33.33^{b}$ & $12.80^{\circ}$ & $31.60^{c}$ & $48.00^{c}$ & $45.00^{c}$ & $69.60^{d}$ & $77.06^{c}$ & $12.68^{c}$ & $13.33^{b}$ \\
\hline
\end{tabular}

Values are means of triplicate readings. Across the same column, mean values with different letters are significantly different at $5 \%$ level according to Duncan's multiple range tests.

F\% (mycorrhizal frequency), M\% (relative mycorrhizal intensity), m\% (absolute mycorrhizal intensity), a\% (absolute abundance of arbuscules) and $\mathrm{A} \%$ (relative abundance of arbuscules). 
Table 6. Parameters of mycorrhizal colonization and abundance of arbuscules in tomato roots grown on solid media at $\mathrm{pH} 6.5$

\begin{tabular}{lccccc}
\hline Treatment & $\mathrm{F} \%$ & $\mathrm{M} \%$ & $\mathrm{~m} \%$ & $\mathrm{a} \%$ & $\mathrm{~A} \%$ \\
\hline Cinnamic acid & $73.33^{\mathrm{b}}$ & $57.10^{\mathrm{c}}$ & $81.57^{\mathrm{c}}$ & $99.84^{\mathrm{bc}}$ & $57.01^{\mathrm{d}}$ \\
Catechin & $53.33^{\mathrm{a}}$ & $48.10^{\mathrm{b}}$ & $72.36^{\mathrm{ab}}$ & $98.29^{\mathrm{a}}$ & $47.07^{\mathrm{c}}$ \\
anhydrous & & & & & \\
Protocatechuic & $100.00^{\mathrm{c}}$ & $66.80^{\mathrm{d}}$ & $66.80^{\mathrm{a}}$ & $99.66^{\mathrm{bc}}$ & $66.57^{\mathrm{e}}$ \\
acid & & & & & \\
Ferulic acid & $80.00^{\mathrm{b}}$ & $57.60^{\mathrm{c}}$ & $72.00^{\mathrm{ab}}$ & $99.41^{\mathrm{bc}}$ & $57.26^{\mathrm{d}}$ \\
Tannic acid & $73.33^{\mathrm{b}}$ & $48.10^{\mathrm{b}}$ & $68.71^{\mathrm{a}}$ & $98.29^{\mathrm{a}}$ & $47.76^{\mathrm{c}}$ \\
Coumarin & $53.33^{\mathrm{a}}$ & $38.50^{\mathrm{a}}$ & $77.00^{\mathrm{bc}}$ & $99.35^{\mathrm{b}}$ & $38.25^{\mathrm{a}}$ \\
Esculetin & $80.00^{\mathrm{b}}$ & $76.60^{\mathrm{e}}$ & $95.00^{\mathrm{d}}$ & $100.00^{\mathrm{c}}$ & $76.00^{\mathrm{f}}$ \\
Catechol & $100.00^{\mathrm{c}}$ & $76.60^{\mathrm{e}}$ & $76.60^{\mathrm{bc}}$ & $99.56^{\mathrm{bc}}$ & $76.26^{\mathrm{f}}$ \\
Control & $53.33^{\mathrm{a}}$ & $38.50^{\mathrm{a}}$ & $71.50^{\mathrm{ab}}$ & $98.29^{\mathrm{a}}$ & $39.01^{\mathrm{b}}$ \\
\hline
\end{tabular}

Values are means of triplicate readings. Across the same column, mean values with different letters are significantly different at $5 \%$ level according to Duncan's multiple range test.

F\% (mycorrhizal frequency), M\% (relative mycorrhizal intensity), m\% (absolute mycorrhizal intensity), a\% (absolute abundance of arbuscules) and $\mathrm{A} \%$ (relative abundance of arbuscules).

parameters (F\%, M\%, $\mathrm{m} \%$, a\% and $\mathrm{A} \%$ ) obtained by using catechin anhydrous at $\mathrm{pH} 6.5$ (Fig. 1) were the most significant values followed by protocatechuic acid (Fig. 2), while all these parameters showed the least significant values by using tannic acid at $\mathrm{pH}$ 5.7. This confirmed our previous results.

Effect of phenolic compounds on production of G. gigantea propagules on solid media

We observed that plates with treatments at $\mathrm{pH} 5.7$ have small and weak roots, so we couldn't take them for examination. But they were more obvious with treatments at $\mathrm{pH}$ 6.5.

As exhibited in Table (6), the mycorrhizal frequency values (F\%) varied significantly from $53.33 \%$ to $100.00 \%$ with different phenolic compounds. Protocatechuic acid and catechol achieved the highest significant values.

Similarly, the values of the other calculated parameters were significantly different by using different phenolic compounds. Esculetin and catechol attained the highest significant M\% and $A \%$ values, while esculetin reached the most significant $m \%$ and $a \%$ values.

From Tables (5 and 6), it was observed, in general, that the values of the parameters of mycorrhizal colonization and the abundance of arbuscules in tomato roots grown on solid media were higher than grown in liquid media.

\section{DISCUSSION}

The moderate appearance of root hairs in control treatments might be because the mycorrhization of tomato plants had a synergetic effect on the root development. In relation to our results, several strains of Glomus stimulated the longitudinal growth in roots ${ }^{35}$. AMF modify the morphology, growth and roots number in maize, leading to more efficient root system in the uptake of minerals and water from the soil ${ }^{36}$.

Arbuscules are brushy branched ends of AMF hyphae which grow in the mycorrhized plant root cells and mediate the metabolic exchange between the host plant and the symbiotic fungus ${ }^{37,38}$.

As observed in results section, catechin anhydrous, which is a flavonoid compound, caused the most significant increase in both mycorrhizal root colonization and abundance of arbuscules. Strengthen this observation; Soares et al. ${ }^{39}$ reported that several flavonoids enhance germination of spores, mycelia growth and colonization of roots by AMF. Quercetin increased spore germination, hyphal elongation, and hyphal branching in Glomus etunicatum. 4',7-dihydroxyflavone and 4',7-dihydroxyflavanone improved Glomus etunicatum spore germination ${ }^{40}$. It was suggested that flavonoids affect the 
arbuscular mycorrhizal root colonization mostly through effects on entry points formation. A nearby relationship between entry points numbers and colonization degree was described. An improved number of entry points resulted in a greater degree of root colonization was detected after application of flavonoids (crysin, luteolin, morin, and rutin) to tomato plants inoculated with Glomus or Gigaspora species ${ }^{41,42}$.

At pH 5.7, Tannic acid inhibited root hairs growth, mycorrhizal colonization and arbuscules formation. In relation to our results, Johnson et al. ${ }^{43}$ informed that phenolic compounds could decrease the AMF colonization. Becard et al. ${ }^{44}$ reported that both kind and concentration of phenolic compounds can affect AM fungi positively or negatively. Kaempferol, myricetin and quercetin enhanced in vitro spore germination and hyphal growth at a concentration $10 \mu \mathrm{M}$. Apigenin, biochanin-A, chrysin and hesperetin at concentrations more than $10 \mu \mathrm{M}$ inhibited in vitro hyphal growth in AMF spores. Fries et al. ${ }^{45}$ discussed that $p$-coumaric acid, $p$-hydroxybenzoic acid and quercetin at concentrations more than 1 $\mathrm{mM}$ inhibited the growth and AMF colonization in clover and sorghum plants. Caffeic, ferulic and vanillic acid at $250 \mathrm{mg} \mathrm{kg}^{-1}$ soil decreased AMF colonization in roots from Sorghum sudanese plants $^{46}$.

The values of mycorrhizal colonization and arbuscular abundance parameters of tomato roots grown on solid media were higher than grown in liquid media. This might be because the immobilization of spores on solid media enhanced the production of spores and hyphae. Also poor aeration in liquid media might hinder AMF development.

Plant roots colonization by AMF in soilless cultures was presented in previous studies. Kowalska et al. ${ }^{33}$ found that the mycorrhizal frequencies in tomato roots inoculated with AMF were 35.79 and $50.82 \%$ at 82 and 112 days after transplanting, respectively. Maboko et al. ${ }^{47}$ attained $78.2 \%$ colonized tomato roots growing in coconut and $77.7 \%$ growing in sawdust. Cwala et $\mathrm{al}^{48}$ found that the colonization level of tomato roots was ranged from 14 to $25 \%$ in hydroponic cultivation.

The $\mathrm{pH}$ of the soil affected growth, mycorrhizal colonization, and uptake of nutrients in
Lygodium microphyllum significantly. Mycorrhizal colonization degree in L. microphyllum roots was significantly low in extremely alkaline and acidic soils. Roots of soil pH ranging from 5.5 to 7.5 recorded high mycorrhizal colonization degree ${ }^{49}$.

\section{CONCLUSION}

Application of phenolic compounds in culture media containing arbuscular mycorrhizal fungi was beneficial. The advantages of in vitro cultures that they can be subcultured, time after time, and yield sufficient aseptic spores. The spores are necessary inocula to serve in beneficial symbiosis in the agriculture.

\section{ACKNOWLEDGMENTS}

None.

\section{CONFLICT OF INTEREST}

The authors declare that there is no conflict of interest.

\section{FUNDING}

None.

\section{AUTHORS' CONTRIBUTION}

All authors have made substantial contribution to the work and approved it for publication.

\section{DATA AVAILABILITY}

All datasets generated or analyzed during this study are included in the manuscript.

\section{ETHICS STATEMENT}

This article does not contain any studies with human participants or animals performed by any of the authors.

\section{REFERENCES}

1. Turnau K, Jurkiewicz A, Grzybowska B. Rola mikoryzy $w$ bioremediacji terenaw zanieczyszczonych. KOSMOS, 2002; 51: 185-194.

2. Song Y, Chen D, Lu K, Sun Z, Zeng R. Enhanced tomato disease resistance primed by arbuscular mycorrhizal fungus. Front. Plant Sci., 2015; 6: 1-13. https://doi. org/10.3389/fpls.2015.00786

3. Manila S, Nelson R. Biochemical changes induced in tomato as a result of arbuscular mycorrhizal fungal colonization and tomato wilt pathogen infection. Asian J. Plant Sci. Res., 2014; 4: 62-68.

4. Dar ZM, Masood A, Asif M, Malik MA. Review 
on arbuscular mycorrhizal fungi: an approach to overcome drought adversities in plants. Int. J. Curr. Microbiol. Appl. Sci., 2018; 7: 1040-1049. https://doi. org/10.20546/ijcmas.2018.703.124

5. Oseni TO, Shongwe NS, Masarirambi MT. Effect of arbuscular mycorrhiza (AM) inoculation on the performance of tomato nursery seedlings in vermiculite. Int. J. Agric. Biol., 2010; 12: 789-792.

6. Bi HH, Song YY, Zeng RS. Biochemical and molecular responses of host plants to mycorrhizal infection and their roles in plant defence. Allelopathy J., 2007; 20: 15-28.

7. Al-Karaki GN. Nursery inoculation of tomato with arbuscular mycorrhizal fungi and subsequent performance under irrigation with saline water. Sci. Hortic., 2006; 109: 1-7. https://doi.org/10.1016/j. scienta.2006.02.019

8. Ryan MH, Angus JF. Arbuscular mycorrhizae in wheat and eld pea crops on a low P soil: increased $Z n$-uptake but no increase in P uptake or yield. Plant Soil, 2003; 250: 225-239. https://doi.org/10.1023/A:1022839930134 9. Charron G, Furlan V, Bernier-Cordou M, Doyon G. Response of onion plants to arbuscular mycorrhizae. 1. Effects of inoculation method and phosphorus fertilization on biomass and bulb firmness. Mycorrhiza, 2001; 11: 187-197. https://doi.org/10.1007/ s005720100122

10. Mukhongo RW, Tumuhairwe JB, Ebanyat P, AbdelGadir $A H$, Thuita M, Masso, C. Production and use of arbuscular mycorrhizal fungi inoculum in sub-Saharan Africa: challenges and ways of improving. Int. J. Soil Sci., 2016; 11: 108-122. https://doi.org/10.3923/ ijss.2016.108.122

11. Abd-Ellatif SA, Abdel-Rahman RA, Mazen MBH, ElEnany AE, Allam N. Biotechnological aspects for VAM aseptic mass production. World Appl. Sci. J., 2012; 17: 20-28.

12. Chandran RP, Potty VP. Arbuscular mycorrhizal fungal inoculum production using Ipomoea batatas hairy roots in bioreactor. ICFAl J. Biotechnol., 2009; 3: 356360.

13. Chandran RP, Potty VP. In vitro co-culture of VAM fungi Glomus microcarpum in Ri T-DNA transformed hairy roots of Vigna vexillata. IJAEB, 2010; 3: 333-338.

14. Mosse B, Hepper CM. Vesicular-arbuscular infections in root-organs cultures. Physiol. Plant Pathol., 1975; 5: 215-223. https://doi.org/10.1016/00484059(75)90088-0

15. Chilton MD, Tepfer DA, Petit A, David C, Casse-Delbart F, Tempe J. Agrobacterium rhizogenes inserts T-DNA into the genomes of the host plant root cells. Nature, 1982; 295: 432-434. https://doi.org/10.1038/295432a0

16. Genre A, Chabaud M, Timmers T, Bonfante P, Barker GD. Arbuscular mycorrhizal fungi elicit a novel intracellular apparatus in Medicago truncatula root epidermal cells before infection. Plant Cell, 2005; 17: 3489-3499. https://doi.org/10.1105/tpc.105.035410

17. Becard G, Fortin JA. Early events of vesicular-arbuscular mycorrhiza formation on Ri T-DNA transformed roots. New Phytol., 1988; 108: 211-218. https://doi. org/10.1111/j.1469-8137.1988.tb03698.x

18. Cheynier V. Phenolic compounds: from plants to foods. Phytochem. Rev., 2012; 11: 153-177. https:// doi.org/10.1007/s11101-012-9242-8

19. Aikawa J, Ishii T, Kuramoto M, Kadoya K. Growth stimulants for vesicular-AMF in Satsuma mandarin pomace. J. Jpn. Soc. Hortic. Sci., 2000; 69: 385-389. https://doi.org/10.2503/jjshs.69.385

20. Romero AGF, Siqueira JO. Activity of flavonoids on spores of the mycorrhizal fungus Gigaspora gigantea in vitro. Pesqui. Agropecu. Bras., 1996; 31: 517-522.

21. Silva-Junior JP, Siqueira JO. Mycorrhizal colonization and growth of soybean influenced by different fungal species and application of the isoflavonoid formononetin. Pesqui. Agropecu. Bras., 1998; 33: 953-959.

22. Steinkellner S, Lendzemo V, Langer I, Schweiger $P$, Khaosaad T, Toussaint J, Vierheilig H. Flavonoids and strigolactones in root exudates as signals in symbiotic and pathogenic plant-fungus interactions. Molecules, 2007; 12: 1290-1306. https://doi. org/10.3390/12071290

23. Scervino JM, Ponce MA, Erra-Bassells R, Vierheilig H, Ocampo JA, Godeas A. Arbuscular mycorrhizal colonization of tomato by Gigaspora and Glomus species in the presence of root flavonoids. $J$ Plant Physiol, 2005a; 162: 625-633. https://doi. org/10.1016/j.jplph.2004.08.010

24. Akiyama $\mathrm{K}$, Matsuoka $\mathrm{H}$, Hayashi $\mathrm{H}$. Isolation and identification of a phosphate deficiency-induced C-glycosyl flavonoid that stimulates arbuscular mycorrhiza formation in melon roots. Mol PlantMicrobe Interact, 2002; 15: 334-340. https://doi. org/10.1094/MPMI.2002.15.4.334

25. Guenoune D, Galili S, Phillips DA, Volpin H, Chet I, Okon Y, Kapulnik Y. The defense response elicited by the pathogen Rhizoctonia solani is suppressed by colonization of the AM-fungus Glomus intraradices. Plant Sci., 2002; 160: 925-932. https://doi. org/10.1016/S0168-9452(01)00329-6

26. Scervino JM, Ponce MA, Erra-Bassells R, Vierheilig $H$, Ocampo JA, Godeas A. Flavonoids exclusively present in mycorrhizal roots of white clover exhibit a different effect on arbuscular mycorrhizal fungi than flavonoids exclusively present in non-mycorrhizal roots of white clover. J. Plant Interact., 2005b; 15: 22-30. https://doi. org/10.1080/17429140500192597

27. Hoagland DR, Arnon DI. The water culture method of growing plants without soil. College of Agriculture, University of California, California, 1950.

28. De Souza FA, Declerck S. Mycelium development and architecture, and spore production of Scutellospora reticulata in monoxenic culture with Ri T-DNA transformed carrot roots. Mycologia, 2003; 95 : 1004-1012. https://doi.org/10.1080/15572536.200 4.11833016

29. Gerdemann JW, Nicolson TH. Spores of mycorrhizal Endogone species extracted from soil by wet sieving and decanting. Trans. Br. Mycol. Soc., 1963; 46: 235244. https://doi.org/10.1016/S0007-1536(63)80079-0

30. Cranenbrouck S, Voets L, Bivort C, Renard L, Strullu D, Declerck S. Methodologies for in vitro cultivation of arbuscular mycorrhizal fungi with root organs, 2005; pp. 341-71. In Declerck S, Strullu D-G, Fortin A (eds.), 
In vitro culture of mycorrhizas. Springer-Verlag Berlin Heidelberg, Germany. https://doi.org/10.1007/3-54027331-X_18

31. Murashige T, Skoog F. A revised medium of rapid growth and bioassay with tobacco tissue cultures. Physiol. Plant, 1962; 15: 473-497. https://doi. org/10.1111/j.1399-3054.1962.tb08052.x

32. Philips JM, Hayman DA. Improved procedures for clearing roots and staining parasitic and vesiculararbuscular mycorrhizal fungi for rapid assessment of infection. Trans Br. Mycol. Soc., 1970; 55: 158-161. https://doi.org/10.1016/S0007-1536(70)80110-3

33. Kowalska I, Konieczny A, Gastol M, Sady W, HanusFajeRska E. Effect of mycorrhiza and phosphorus content in nutrient solution on the yield and nutritional status of tomato plants grown on rock wool or coconut coir. Agric. Food Sci., 2015; 24: 39-51. https://doi. org/10.23986/afsci.47204

34. Trouvelot A, Kough JL, Gianinazzi-Pearson V. Mesure du taux de mycorrhization VA d'un systeme radiculaire. Recherche de methodes d'estimation ayant une signification fonctionnelle, 1986; pp. 217-221. In Gianinazzi-Pearson V, Gianinazzi S (eds.), Mycorrhizae: physiological and genetical aspects. INRA-Press, Dijon, France.

35. Fidelibus MW, Martin CA, Wright GC, Stutz JC. Effect of arbuscular mycorrhizal (AM) fungal communities on growth of 'Volkamer' lemon in continually moist or periodically dry soil. Sci. Hortic., 2000; 84: 127-140. https://doi.org/10.1016/S0304-4238(99)00112-0

36. Kaldorf $M$, Ludwig-M ller J. AM fungi might affect the root morphology of maize by increasing indole-3-butyric acid biosynthesis. Physiol. Plant, 2000; 109: 58-67. https://doi.org/10.1034/j.13993054.2000.100109.x

37. Wells JE, Varel VH. Symbiosis of plants, animals, and microbes, 2011; pp. 185-203. In Pond WG, Bazer FW, Rollin BE (eds.), Animal welfare in animal agriculture: husbandry, stewardship, and sustainability in animal production. CRC Press, New York.

38. Parniske M. Arbuscular mycorrhiza: the mother of plant root endosymbioses. Nat. Rev. Microbiol., 2008; 6: 763-775. https://doi.org/10.1038/nrmicro1987

39. Soares ACF, Martins MA, Mathias L, Freitas M S M. Arbuscular mycorrhizal fungi and the occurrence of flavonoids in roots of Passion fruit seedlings. Sci. Agric., 2005; 62: 331-336. https://doi.org/10.1590/ S0103-90162005000400005

40. Tsai SM, Phillips DA. Flavonoids released naturally from Alfalfa promote development of symbiotic Glomus spores in vitro. Appl. Environ. Microbiol., 1991; 57: 1485-1488.

41. Scervino JM, Ponce MA, Erra-Bassells R, Bompadre J, Vierheilig H, Ocampo JA, Godeas A. The effect of flavones and flavonols on colonization of tomato plants by arbuscular mycorrhizal fungi of the genera Gigaspora and Glomus. Can. J. Microbiol., 2007; 53: 702-709. https://doi.org/10.1139/W07-036

42. Scervino JM, Ponce MA, Erra-Bassells R, Vierheilig H, Ocampo JA, Godeas A. Flavonoids exhibit fungal species and genus specific effects on the presymbiotic growth of Gigaspora and Glomus. Mycol. Res., 2005c; 109: 789-794. https://doi.org/10.1017/ S0953756205002881

43. Johnson NC, Copeland PJ, Crookston RK, Pfleger FL. Mycorrhizae: possible explanation for yield decline with continuous corn and soybean. Agron. J., 1992; 84: 387-390. https://doi.org/10.2134/agronj1992.00 021962008400030007x

44. Becard G, Douds DD, Pfeffer PE. Extensive in vitro hyphal growth of vesicular-arbuscular mycorrhizal fungi in the presence of $\mathrm{CO}_{2}$ and flavonols. Appl. Environ. Microbiol., 1992; 58: 821-825.

45. Fries LLM, Pacovsky RS, Safir GR, Siqueira JO. Plant growth and arbuscular mycorrhizal fungal colonization affected by exogenously applied phenolic compounds. J. Chem. Ecol., 1997; 23: 1755-1767. https://doi. org/10.1023/B:JOEC.0000006449.09141.cd

46. Piotrowski JS, Morford SL, Rillig MC. Inhibition of colonization by a native arbuscular mycorrhizal fungal community via Populus trichocarpa litter, litter extract, and soluble phenolic compounds. Soil Biol. Biochem., 2008; 40: 709-717. https://doi.org/10.1016/j. soilbio.2007.10.005

47. Maboko MM, Bertling I, Du Pplooy CP. Arbuscular mycorrhiza has limited effects on yield and quality of tomatoes grown under soilless condition. Acta Agric. Scand. B-S P, 2013; 63: 261-270. https://doi.org/10.1 080/09064710.2012.755219

48. Cwala Y, Laubscher CP, Ndakidemi PA, Meyer AH. Mycorrhizal root colonisation and the subsequent host plant response of soil less grown tomato plants in the presence and absence of the mycorrhizal stimulant, Mycotech. Afr. J. Microbiol. Res., 2010; 4: 414-419.

49. Soti PG, Jayachandran K, Koptur S, Volin JC. Effect of soil $\mathrm{pH}$ on growth, nutrient uptake, and mycorrhizal colonization in exotic invasive Lygodium microphyllum. Plant Ecol., 2015; 216: 989-998. https://doi. org/10.1007/s11258-015-0484-6 